\title{
The Last Kings of Ireland
}

R ODERICK O'CONOR'S assumption of the Irish monarchy was $\mathrm{R}$ in more senses than one what we should now call ' $a$ walk over.' On the death of his predecessor he mustered his horsemen and footmen, and, with warlike Connaught at his heels and allies and visseals streaming to meet him at every point, went round Ireland in a leisurely, uneventful style, collecting hostages and receiving tributes, and was in Dublin 'insugurated king of Ireland in as honourable a manner as any king that preceded him.' Returning to Connaught, he locked up his hostages ${ }^{1}$ in an island ${ }^{2}$ on the Bhannon, and proceeded to hold parliaments, conventions, 'fairs;' to raise up, pull down and expel-in short, to exercise all the functions of his office. The strongest of the provincial kings he discrowned ${ }^{3}$ without exertion. All this, however, was quite abnormal and almost sui generis. That the reader may learn something of the 'anarchy' which prevailed in Ireland during this century, of those intestine wars of which he has heard so much and been told so little, it will be necessary to ignore, at least at present, those state-progresses of Roderick through the island. A normal Irish king had to clear his way through the provinces, battle-axe in hand, gathering hostages by the strength of his arm, and prove himself incontestably 'Bellona's bridegroom, clad in proof,' before the coy island would accept him for her lord.

I propose in this paper to touch lightly on the history of the eleventh century, just enumerating the kings and suggesting their quality, but to relate with some fulness of detail a portion of the history of Roderick's father, Turlough, a much more interesting character, whose reign is typical of the social and political condition of Ireland in the twelfth century. Moreover it was this Turlough who created that western or O'Conor hegemony which Roderick inherited, and planted with infinite pain and labour the tree of

1 Annals of the Four Masters, an. 1167. He gave the Danes, howerer, a retaining tee of 4,000 cows, levied ofi the men of Ireland for their use. The cor was a anit of value, representing at this time $3 \mathrm{oz}$. of silver. This value of the cov is provable trom the Arrals.

Inis Clohran, on Lough Ree, the state prison of the provinoe.

- Dermot MaoMurrough, king of Leinster. 
which Roderick gathered the fruit. I hope to shed a little light upon a period hitherto not so much obscure as blank to nearly all historical students. The authority upon which I chiefly rely is the 'Annals of the Four Masters;' I have consalted also various other works bearing on the period, such as the 'Annals' of Clonmicnoise and Loch Ce, Keatinge's History, the Manx Chronicle, and Usher's 'Sylloge Veterum Epistolaram Hibernicarum.'

It has been doubted whether there was ever a king of Ireland. This is at least certain : that there were puwerful Irish dynasts who were called kings of Ireland by foreign writers as well as native. Such a chief was by Latin authors termed rex Hibernice, rex totius Hibernia, and imperator Scotorum, and by Gaelic Ard-Rig, or high king, a word which I propose to write Ard-Ri. What manner of men were these Ard-Ris ?

We need not here concern ourselves with the pre-Scandinavian history of Ireland otherwise than to observe that the hegemony of old belonged to the north rather than to the south. So far back as the legendary period, the age of the Hounds, ${ }^{4}$ the military preponderance of the hardier northern nations is clearly apparent. The Irish monarchy, and all that it meant in that more primitive form of society, were an appanage of the dynastic houses which claimed descent from Nial of the nine hostages, captain of the Irish or Scoti in the great convulsions which attended the break-up of the Roman empire in the north-west of Europe.

The history of Ireland in the eleventh and twelfth centuries is the history of a race evolving its monarchy, and is therefore likely to prove a valuable contribution to general European history. For, the process which in most other countries is sunk in oblivion lies all revealed in Ireland; so generous have been our monkobardic historians. The risings and fallings of dynastic clans, the whole of the vast and bloody, but not ignoble, strife are described with accuracy and minateness. In Ireland, as elsewhere, the creation of the Irish monarchy was the result of the natural selection of the best of the dynastic families in the island. For this result there was no other method possible, nor, I think, conceivable, вave that of war. The best family had to fight its way to the front, and by elear force majessre set its feet on the necks of the rest and rule, in the beginning at all events and for certain generations, by no other law than that of the sword and battle-axe, with some little assistance from tradition and the doctrine of hereditary right.

The hegemony lay with the north, and all the bardic traditions were upon the side of the descendents of Nial. But in the tenth century there emerged in the south of Ireland a remarkable person-

- The two centaries that surround the Incamstion form the heroio period of Irish history. The Irish spoes are cu-raidhe, i.e. hoond-sprong. 
ality, a man who by his own intrinsic superiority, and against all custom and tradition, forced his way to the captaincy of the whole island-Brian Boroma, vulgarly known as Brian Ború, i.e. Brian of the Tributes. Readers have heard of Cin-cora, the celebrated O'Brian stronghold at Killaloe, on the Shannon. A mile northwards from this fort was another, called Boroma; and the two were connected by fortifications ${ }^{5}$ of earth and timber, the whole forming one of the greatest strength yet known in the island. It was indifferently known as Cin-cora or Borome, though in latter times the genius of Moore has indissolubly connected the former name with the schievements of Brian and of his successors. The steady advance of Brian from the position of a sort of Robin Hood, or inferior vassal of the Danes of Limerick, to the unchallenged lordship of the whole island supplies an excellent example of how an Irish king was made. The bardic history of his progress to monarchy will be found in Dr. Todd's 'Wars of the Gredil and the Gaill,' from which one who understands the bardic methods of historiography can deduce the facts with tolerable exactness.

One by one the dynastic houses submitted to Brian's overlordship, rendering tributes and hostages, till in presence of the dignitaries of Ulster, lay and clerical, Brian by the hand of his chief secretary had himself inscribed imperator Scotorum in the 'Book of Armagh.' The curious may still see that ancient entry by paying a visit to the library of Trinity Colloge, Dablin.

A new and powerfal family started from the loins of Brian Ború, not unnaturally taking their tribe name from him, viz. the O'Brians. But in time the force communicated by their great ancestor failed. Strongbow and his companions found the O'Brians decidedly worsted in the great struggle of the rival dynastic houses. The mouth of the battle-axe, arbiter of the strife, otherwise still stammering, had given a clearly adverse decision to O'Brian pretenBions.

Brian was succeoded as Ard-Ri by Melaghlin,, king of Meath, and as chief of the Dal-Cas, his own nation, by his son Donough, who led the retreat from Clontarf and immortalised himself by the way. Donough and his war-worn handful fought their wey home through hostile territories, sorely harased by the king of Ossory and others. In one of these battles the wounded of Clontarf fought in their ranks supported by atakes driven into the earth. This heroic Donough of the retreat succeeded Melaghlin ar Ard-

- Bee O'Donoran's notes to the translation of the Anorals of the Bour Mattora, AD. 1117.

- Whom he had previoualy deposed, and who, though present at Olontart, took no part in the bettle. 'Stand aside, $O$ ex-hing; wo will beat these torelgners without jopr aid,' quoth the Dal-Ces. Bach at least is the story. 
Ri, though his Ard-Riship was vehemently opposed. ${ }^{7}$ After a stirring reign he was eventually deposed by his own people, and went on a pilgrimage to Rome, where he died.

Dermot MacMaol-na-m-bo, king of Leinster, succeeded him a-s Ard-Ri-Ard-Ri with opposition and plenty of it. Nevertheless foreign writers invariably refer to him as king of Ireland, finding him so regarded at the great sea-ports. To his protection fled the sons of Earl Godwin, Harold and his brother Leofwin, upon the expulsion from England of that powerful house by Edward the Confessor. "They passed the winter under the protection of King Dermot in Ireland.' ${ }^{9}$ Again, ' Harold went westward into Ireland, and was there a whole winter under the king's protection.' 10 Mr. Freeman congratulates Lappenberg apon his acuteness ' in having perceived that, odd as was the expression, an Irish king must be meant.' Why odd? Plainly because even Mr. Freeman could only picture Ireland as the scene of waste tribal confusions, aimless flockings and fightings, a wilderness tenanted by wolves and wolfish men, girt by a little illuminated fringe of Danish order and civilisation. Yet the Danes had little influence in the country, were subjects of the inland dynasts, and evidently regarded this Dermot not only as their king, but as the king of Ireland, communicating that impression to contemporary historians in England.

From the protection of this Dermot young Harold returned to assist his father, communding a small Irish fleet and army. All Danes, writes Mr. Freeman, determined to see in Ireland nothing but the Scandinavian fringe.

To the power of Harold's host and protector succeeded a young protégé of his, Turlough O'Brian, son of Teigue, son of Brian Ború and nephew of Donough of the retreat from Clontarf and the Ossorian battles. This dynast did conquer all Ireland, had in ward the hostages of the whole nation. Like his grandfather he was rex

'Dr. Todd's Wars of the Gaedil and the Gaill, also Kestinge's History. Derrorgille was descended from Brian Bort through Donough.

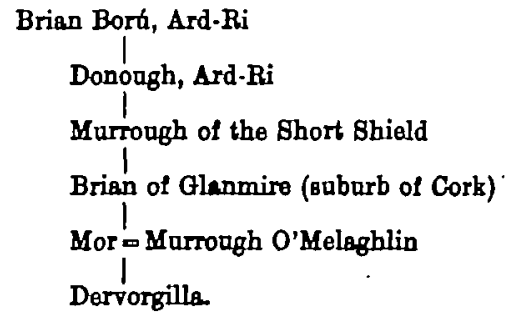

- i.e. son of Marrough Maol-na-m-bo (slave or fosterling of the cows-cow-narsed perheps). This Murrough is the stirys of the Clan MacMurrough, clan regnant of Loinster, and ancestor of Dermot MacMurrough.

- Life of Edward the Confessor, 404.

10 Paterborough Chronicle. These entries are quoted from Mr. Freeman's History of the Norman Conquest, ii. 154. See also Lingard's History of England, i. 448. 
totius Hibernia and imperator Scotorum." There is a letter to him from Lanfranc, archbishop of Canterbury, addressed Magnifico Hibernico regi Terdelvacho.' 12 Keatinge relates that Turlough was on friendly terms with William Rufus, and sent him timber for the roofing of Westminster Abbey.

Turlough was succeeded by his son Murty, under whom the O'Brian hegemony reached its highest point. He was full Ard-Ri of Ireland, and through his son Donald, king of Dablin, was lord of the widely extended maritime and insular confederacy of which Danish Dablin was then the head. A glance at the O'Brian genealogy will not be here amiss.

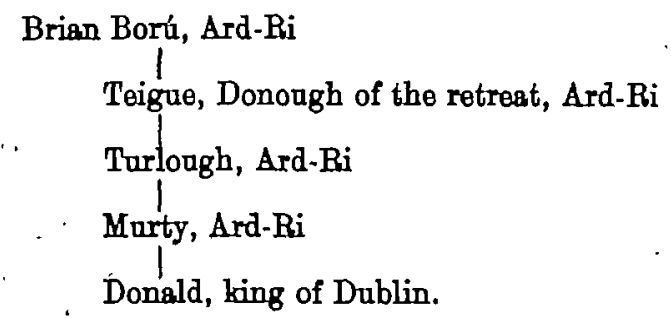

According to the Manx Chronicle the Hebridean Danes begged a king from Murty, and Murty gave them Donald. I rather think he was ruler of the islands in consequence of his position in Dublin. During Murty O'Brian's reign Magnus, king of Norway, came down into these waters. With his own hand he slew Hugh Lupus, earl of Chester, and did other doughty things. The Manx Chronicle says that Murty did him a peculiar homage, i.e. walked barefooted before him. The son of Magnus, Sigurd the Crusader, married a daughter of the Irish king. Another daughter, Lafracoth, married Arnulf de Montgomery, brother of Robert of Belesme. Murty and Magnas were both in the great leagne formed against Henry Beauclerc by the western earls. Nevertheless William of Malmesbury relates that Murty and King Henry were afterwards good friends.

"Mr. Hallam's note on the Bretwaldas poold never have been written hed he atudied Irish contemporary histery. A Saxon Bretwalda, imperator totius Britannia, is not at all a notion to be leaghed at if one understands what ringship and overkingship meant in those deys. Columbe at the court of the Pictish king Brude found there in fetters the hostages of the Orkneys, as related by Adamnan. The Bretwaldsship was quite possible, and when the Saron chronicle describes a Northumbrian king as imperator totius Britannice I for one have little doubt as to the truth of the description-at least noe no antecedent improbability.

1 In Usher's Syllogo Tat Hapist. Hibern. Epistola xxvii.

11 The Norse serge of Kung Magnus relates this vividly. Bo does Orderic, pp. 767, 768. The saga calls Murty Monartak, whiah is nearly the correct pronunoiation of Muir-Ceartach, and describes him as king of Ireland. Mr. Freeman, who invariably loses himselt when he gets iun the interior, calls him Murtagh 'of Connanght,' the $O$ 'Brians being a notoriously Munster family, and in an astonishing manner compares him with the father of Dermot MacMurrough. 
In the Norse saga of Magnus, our Irish king is called Moriartak O'Brian. The Grelic form is Muir-Ceartach, i.e. Wall of Righteousness. He and Magnus warred a good deal, both as foes and allies. Magnus was slain in those wars by the Ulidians of the county of Down. There is a full-length picture of the battle in the saga, admirably graphic and evidently the work of an eye-witness. Carlyle, referring to this battle, says, 'Place, I regret to say, altogether undiscoverable to $m \theta$; known only that it was boggy in the extreme,' which it most decidedly was - very boggy, yet with 'holmoaks' growing therein, as the old skald particularly mentions."

I have exhibited these kings in power, but not the steps by which they gained and held it. The progress of an Irish chieftain to monarchy I reserve for my treatment of my typical king, Turlough, father of Roderick. As to the Ard-Riship, it must be remembered that there was no such thing as general election even of the Polishdiet description. He who would be Ard-Ri had to move forward step by step, battle-axing territory after territory into submission to himself and the tender of hostages. Now he grasped a barony, now a county; now meeting in battle another candidate who had similarly subdued wide regions, he overthrew him and became lord of whatever tribes and territories the latter had previously brought beneath his sway. There is no trace of tribal warfare in the history of these centuries. All the wars are of dynastic kings warring upon kings to essert dominion or retain independencea most salutary warfare, inevitable, indispensable, enjoined by nature herself. Tribes and nations had ceased to count; of each generation the history is that of some half-dozen strong men striving for the inastery. They stand out from the rest like giants, like Homer's herves among the ruck of Greeks and 'Trojans. The chronicles distinctly lend themselves to this suggestion of gigantomachir in such phrases as the following: 'Turlough O'Conor and Tiernan O'Rourke were terribly at war these years-Ireland a shaking sod between them.'

How naturally out of the traditions of such strife would the primitive imagination evolve combatants of superhuman power. In truth this was the grand age of individualism. The church, unorganised, had no power; the Brehon law did not check kings; the tribal control had ceased; old rules and customs were inapplicable to the new order of things; the minor chieftains feebly checked the king. Giraldus expressly tells as that Dermot MacMurrough tyrannised savagely orer his nobles. So, released from all controlperhaps purposely released to that end by formative nature, eager

"History of the Kings of Norvay, p. 87, People's Edition. Carlyle calle Murty Mardog, and seems to quis him in the name. Of Magnas in Irelsnd and of 'Murdog ' he really knew nothing. For picturesqueness he gives the Irish kings of the period Elizsbethan costumes, remembering something about Shane O'Neill and his gaards. 
to get the work done at no matter what cost-these half-dozen kings fiercely battled like bulls for the mastery of the herd. Nature, intent on her own purpose, made them as free as possible, as strong as possible for the dire struggle. Curiously enough too there is no trace of personel malignity between these warring kings, no fixed enduring feuds. They were allies and foemen and foemen and allies as the fast-spinning wheel of change revolved, bringing up controversy after controversy, for whose solution there was no other adequate tribanal save their supreme court of battle-axes.

So far the Irish Ard-Ris, down from Brian Ború, are as follows :-

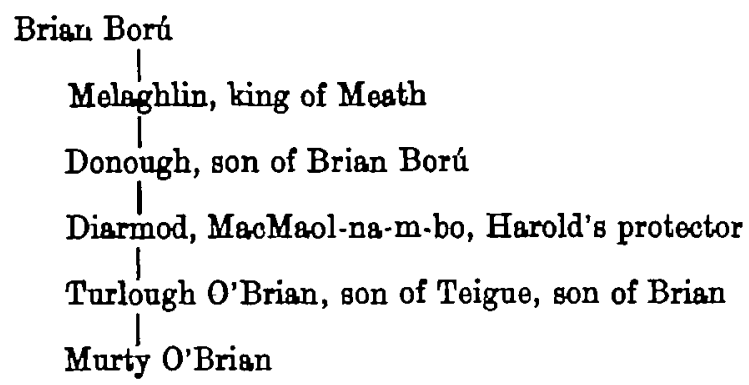

1106. Murty O'Brian, king of Ireland, marched into Connaught, deposed the reigning $0^{\prime}$ Conor, and planted in his room a young scion of the same stock, a lad of eighteen, but tall, spirited, full of promise, and his own nephew. It was Turlough Mör O'Conor, father of Roderick, the last Irish king. Turlough, recte Toir-dealbach, means tower-shaped or towering, and the epithet Mōr means, not great, but tall. Standing on the tomb of the ancient god Fraech, hard by the Shannon, Ard-Ri Murty preaiding, the boy was inaugurated the $0^{\prime}$ Conor and king of Connaught with antique ceremonies. ${ }^{16}$ The Ard-Ri gave him the hostages of the province, gave him warnings and good counsel, perhaps a share of his military strength, and marched away to attend to other businesses, for an Irish Ard-Ri in these stormy times had need to be very swift and expeditious in all his movements. Not much grass grew under a king's feet in the twelfth century. So young Turlough, at the age of eighteen, found himself king of a province, there to stand or fall as he was found fit or unitit.

The boy came of a line of distinguished sires, all in their time captains of Connaught. He was son of Rory Yellowspear, son of Hugh Breakspear, son of Teigue of the White Steed, who was the first $\mathrm{O}^{\prime}$ Conor, being son of Cathal and grandson of Conor, root of the clan and ancestor of all the O'Conors. His father, Rory, formerly king of Connaught, many years since had been taken and

1. There were usually tro inangurations, one pagan, with the ceremony of the wand, \&c., the other ecclesiastical, with oil of consecration. 
blinded by a fierce sub-chieftain, the O'Flaherty of Jar-Connaught. ${ }^{16}$ This better than a detailed description will show over what manner of men our eighteen-year-old king was called upon to rule, and what work lay before him. Turlough $0^{\prime}$ Conor is a known name in Anglo-Irish history, but those sires of his with uncouth barbaric titles were famous also in the Ireland of the eleventh century Yellowspear and Breakspear and the knight of the White Steed were brave and strong in their day. They fought, ruled, and diplomatised with energy and success in those trans-Shannon regions, creating that $O^{\prime}$ Conor imperium which this boy was destined to carry so far, and Roderick, his son, so much farther. They overthrew, tamed, or exterminated divers western gentes, expelling thence another great rival clan, the O'Rourkes, whom they confined to a kingdom called Breffney, on the mearings of Connaught and Ulster, where we shall meet them again under the captaincy of one whose name at all events is familiar to the reader, Tiernan O'Rourke, husband of Dervorgilla. Connaught too had been electing her clan regnant, and the mouth of the battle-axe had given a very decisive vote in favour of the house of Conor.

I pass over the next eight years of Turlough's life. . It was spent in governing his province and keeping a proad, rebellious chieftainry in subjection-a terrible task, which, however, he successfully accomplished. That young Turlough did his domestic work well we know from this : that even in seasons of the greatest misfortune he never lost his hold upon the province. He had doubtless his mild methods and winning ways too-he was surnamed Augustus, surely for good reasons-but for the recalcitrant always ready battle-axes and trained troops of swift raiders and plunderers. By mild methods and fierce-chiefly the latter-the boy proved that Connaught was his and not O'Flaherty's or any other's. We catch stray glimpses of him campaigning and plundering there, as it were proving his title in that western court of battle-axes. But we may be very certain that he had much hard work to do, as we know that he did it well. To use a bardic simile, Connaught, though anything but a tame steed, conld not throw him. In the and he rode Connaught like a well-trained war-horse. The bards compare him to Augustus, struck, I think, by some resemblance in administrative methods. In a sense no doubt the comparison is absurd. Yet I think the government of the formed and settled Roman empire was but child's play to the task of ruling Connaught in the twelfth century. Of Turlough $O^{\prime}$ Conor, surnamed Augustus, I take up the story again in the year 1114, when he first crossed the Shannon intent on greater things-a man-tamer, interesting in himself and interesting as a type of the primitive Irish dynast.

14 Arrals of Loch Ce, 1118. He lived 86 years in blindness. 
1114. Murty O'Brian, the Ard-Ri, fell strangely sick, for we are told that 'he became a living skeleton.' His chiefs deposed him, and elected his brother Dermot in his room. Down from the north dropped Donald O'Loghlin, the old king of Ulster, with all his host, to take the Ard-Riship, thus vacated. Submissions and hostages poured in to him on all sides as he went. The red hand of Ulster seldom exhibited itself in these dynastic wars without proving itself a strong centre of attraction. Despite the longsustained power of the O'Brians, many men-most perhaps-still believed that the true root of the Ard-Riship was in the north, was in the descendants of Nial of the Nine Hostages. With an army daily augmenting, old Donald reached Ballinasloe: Thicher, with hostages, came young Turlough O'Conor to meet him, a welcome ally..$^{17}$ He was only 26 years of age; but warlike Connaught, well battle-axed and well ruled, well scourged and well conciliated, followed submissive at his heels. Turlough's brother, indeed, at this juncture rebelled or caballed, leaning to the $0^{\prime}$ Brian interest, bat was speedily suppressed and taken prisoner by Turlough. The whole joined host now entered Munster. After some delay and complications, which need not detain us, O'Brian opposition subsided and the old northern king took the Ard-Riship of the island.

He was 65 years of age and held the dignity for seven years, dying in 1121. 'The storm-and-stress' period of his life was earlier. He had fought against Murty $O^{\prime} B r i a n$ and against Magnus, king of Norway, and against both combined, and had beaten the former in a pitched battle and killed Magnus in a skirmish. It was felt by all that he deserved his Ard-Riship. He got it and, what is more remarkable, enjoyed it. An Irish Ard-Ri might indeed lead a fairly quiet life, if he was content with homages, hostages, and clearly admitted tributes and privileges. These were fixed by ancient custom. They will be found clear and explicit in the Brehon treatise known as the 'Book of Rights.' But all political power instinctively aims at aggrandisement. Moreover the genius of the age more and more imperatively demanded a new type of kings, who would not be satisfied with the annual receipt of so many ships from Waterford and swords from Ossory, cloaks, slaves, cattle and sheep, gold, \&c., tributes, gifts, homage, and precedence, but who would intervene strongly in dynastic quarrels and make their power felt and their persons feartd. Donald was old : his ideas were primitive and he was satisfied with customary tributes and homages. Once at least he intervened strongly in the affairs of the island, descending like a sort of deus ex machina, bat on the

17 The Arrals of Loch Ce state that the king of Tir Connall, i.e. Donegal, came with Turlough. From this and other indications I thint Donegal was in Turlough's time included in Connagght. 
whole remained quiet in his northern home, enjoying his fame and his position and his great revenues.

Young Turlough was left free to do much as he pleased, a youth whose ideas were very different as to the duties and prerogatives. of kings.

Things being settled on this basis, with a whole network of new treaties covering the country in consequence, all Ireland was startled with the news that the old sick Dal-Cassian lion was up and out again. Pale and lean old Murty reappeared on the scene, took his brother prisoner, and resumed the O'Brianship. Far up into the island he marched, ressserting his overlordship. Amongst other feats he netted and drove the cattle of a territory at night by the light of firebrands. ${ }^{18}$ He joined hands with his son Donald, king of Dublin, who on his side had beaten the Leinster men in battle, and together they broke down the new combinations far and wide. But this mysterious sickness would not relsx its hold upon the old king. Yielding to its stress and to no other, he stooped at last to the inevitable : after a few months he retired from the field a contirmed invalid. Murty died in 1119 , ' flood of the glory and magnificence of the west of the world.' Again from far and near the tributes of Ireland flowed to the primitive northern king. That unexpected outbreak from the sick chamber was but a slight, transient interruption of the northern man's Ard-Riship.

During this short crisis young Turlough O'Conor remained true to the new Ard-Ri. He was treaty-bound and, moreover, the Ulster man had his hostages. While old Murty and his son, the king of Uablin, were operating in the midlands Turlough crossed the Shannon, devastated Thomond, and returned with flocks and herds and captives. These secured, he made another hosting, and struck out this time eastward, to resettle the interrupted arrangements in the midlands, true to the overlord's interests-truer perbaps to his own. Within that northern hegemony, not impinging upon or conflicting with its simple tribute-taking character, he would establish one of his own, and he did. Collecting his fleet of river galleys-for Turlough was strong upon the waters, salt and fresh-he sailed up the Shannon to Longford, and, spite his formidable patronymic, conquered the son of Hound-of-the-Mountain 0 'Farrell, lord of that country, and fortified and garrisoned 'the Yellow Land of the Birch Trees.' Having so hand-locked the O'Farrell he descended the Shannon. Merry sang the monks of St. Ciaran as King Turlough rowed by, for there was friendship between the famous monastery of Clonmicnoise and the $O^{\prime}$ Conors. Young Turlough paused in his rowing; his spoil-laden galleys

\footnotetext{
12 He took 'the Prey of the Firebrands,' relate the Four Masters. This points to a bardic tale growing out of the adventure $-a$ tale possibly still in existence.
} 
dropped anchor before that ' land of roses,' 19 churches, and tapering towers. Turlough went ashore and laid on the altar of Ciaran a chalice of gold and silver, ${ }^{20}$ and a drinking horn of gold, and a copper dish all charged with gold--a firstfruits offering to one who was a sort of god to the western Irish. Old blind Rory Yellowspear heard that day the rowing of the galleys and embraced his son for the last time. He died next year, after some twenty years of stormy life and thirty-six of blindness.

Turlongh's 'jewels ' were, not long after, stolen from the high altar by an Irish Dane of Limerick, who, however, could not get out of Ireland with his plunder, though he sought successively the ports of Limerick, Cork, and Waterford. The conscience-stricken wretch saw 'Ciaran with his crosier stopping every ship on which he embarked.' Finally he was taken and hanged by a young southern king, Conor Slapar-Salach 0 Brian, and Turlough's jewels were restored to their place on the high altar. There was plenty of wild superstition mingled with the piety of the age. About this time the chroniclers report the eppearance of 'demon-ships in the Bay of Galway, and they sailed against the wind ;' and men still feared the pagan deities more than they would admit, potent and terrible beings known as the Sidhe.

Returning home Turlough made a new hosting, crossed the Shannon, entered Mesth, and divided that kingdom into halves, setting up there two kings, one of them Murrough, the father of Dervorgilla. His name appears as Murchard Hu Melaghlin in Henry II's grant of Meath to Hugo de Lacy. 'I grant him,' wrote Henry, 'all Meath, to be held by him in as ample a manner as it was held by Murchard $\mathrm{Hu}$ Melaghlin or any other king of the same.' This clan had been, and perhaps was, of royal dignity. The root of the family was that Melaghlin who would not help Brian Ború at Clontarf, but stood aside a spectator and took the Ard-Riship when the old hero was killed. Since then the O'Melaghlins had been weighed in stern balances and found wanting.

King of Connaught and lord of Meath and master of Longford, the young conqueror now turned southwards. Here a grand struggle awaited him. The O'Brians, with all their proud traditions down from the days of Clontarf and further, had no notion of submitting to this youth, whom they regarded as their own protégé. But the harrying which he had administered to them during ArdRi Murty's outbreak was severe. The ensuing winter was terribly

1. 'In a quiet watered land, a land of roses, Stands St. Ciaran's city fair, And the warriors of Erin in their famous generations Slumber there.'

T. W. Rollestone's translation of an Irish poem.

- Irish metallargy, now at its height, was an art greatly respected by the chieftains. 
stormy and cold, and famine and plague had succeeded that harrying and that winter. Nevertheless they were still lords of Munster, Leinster, and of the Danes. Turlough a second time devastated Thomond by way of enforcing submission, and again brought away flocks and herds and captives. Nevertheless he restored the latter ' to God and to Flannan.' 11 It is significant of Turlough's character that the archbishop of Armagh the same year made a circuit of Turlongh's dominions and received his full tribute. Tarlough was very friendly to the church, in this century a beautiful characteristic of kings, for the church was entirely deserving.

The O'Brians made a return invasion of Connaught under their new king, Dermot, brother of the live skeleton, but were met and overthrown by Turlough on the 'Hill of the Red Birch Tree,' in South Connaught. Next year, 1117, the O'Brians tried again. They even penetrated into North Connaught, but were driven thence by Turlough, pursued, and decisively overthrown in 'the rushy plain of Oran,' county Tipperary, and overthrown anew in a third battle at Lacken, county Clare.

Leaving now behind him the O'Brian hegemony, sorely battered, young Turlough made a new hosting, and crossed the Shannon eastward with his face to Dublin. Subject Meath joined him on the march. At the head of a great army he appeared before Dublin. The Danes threw open their gates before the young conqueror. Thence he expelled their O'Brian king, Donald, son of Murty, the live skeleton, and sent him to Lismore as a monk. Another than Turlough would have killed or blinded such a man as Donald O'Brian, son of an Ard-Ri. The Fusti tell us that Turlough was ' full of mercy and compassion.' At all events on this occasion he allowed beaten Donald to retain his eyes and retire to a monastery, and he took to himself the hostages of East Ireland, whom Donald previously held in the castle in Dublin, and took also the hostages of the Danes. Also there came to him the men of Leinster and the men of the kingdom of Ossory with theirs. Then, with all his gyved pledges, Turlough returned home and recrossed the Shannon, having torn East Ireland from the hands of the O'Brians.

Again the same year he made a new hosting and marched southwards to deliver a finishing stroke at that powerful house whose 'Strong Hand Uppermost' ${ }^{2}$ began now to wear sach a rueful aspect. He attacked and stormed Kincora, and hurled the fortifications, both stone and timber, into the waters of Lough Derg. So conspicuously this young western dynast set his stroug foot on the necks of the O'Brians, announcing to all men that their hegemony was at an end. $\mathrm{He}$ rebuilt the plank bridge of Killaloe, and past the smoking roins of the great 0 'Brian eyrie, famed in a

I Patron saint of Killaloe.

$n$ The O'Brian motto. 
thousand songs, having with him as vassals the king of Meath and the king of Breffney, marched into Munster. He pitched his cemp under the walls of Cork, summoned to him the chiefs of the province, and divided Munster into three parts. Orer Desmond he set a MacCarthy, and over Thomond the two sons of Dermot, now dead, viz. Conor Slapar-Salach O'Brian and Turlough O'Brian, and brought with him the hostages of the province. Conor Slapar-Salach means literally Conor of the Dirty Skirts. I fancy he introduced the fashion of trailing mantles, and got ridiculed, as introducers of novelties will. I picture him as a rather magnificent young man inclined to by sumptuous. Subsequently he became a dangerous rival of Turlough $0^{\prime}$ Conor, and had a rather considerable career, being at one time more then half king of Ireland. He is celebrated in the Chronicle of Ratisbon as the chief builder of that monastery. The prsssge is well known to students of Irish history; it is quoted in Lynch's 'Cambrensis Eversus' and also in Miss Stokes's recent work on Irish art.

Next year, having as it were built his house, he proceeded to purify it. He summoned to him Enda, king of Leinster, and the king of Leix.2 All three went up and down the Shannon in Tarlough's fleet, hanging ${ }^{24}$ water-robbers and destroying their forts and bars. These were Danish robber lords, who preyed upon the commerce of the great water highway of the west. These two extern kings and their forces he sustained with the new rents accruing to him out of conquered Munster. So Munster paid two rents, one to Donald O'Loghlin, the Ard-Ri, and one to Turlough. Donald was their suzerain but Turlough their master.

Dervorgilla's father, Murrough, king of Meath, now gave offence. ${ }^{25}$ Turlough threw bridges across the Shannon, invaded Meath, and deposed him and resettled that province, taking hostages of the sub-chiefs. The archbishop of Armagh was guarantor of this new arrangement. But the old Ard-Ri took fire at this. His young lieutenant seemed to be playing unheard-of pranks in the south; old Donald dropped down to inquire into the matter, and Turlough, putting first the Bhannon between himself and the irate monarch, hod seemingly to relinquish his intentions. 'He made a false peace' ${ }^{25}$ with the Ard-Ri ; but this did not mean much, for the same year he rebuilt his bridges and stepped in a very lordly fashion into Meath, as if he were the one great and strong king of the island. Turlough built as many bridges as he fought battles. They were pontoon bridges, defended with fortified bridge-heads. Stepping

Queen's County.

" For this interesting fact see the Arrals of the Four Masters, 1119.

- He had in the interim killed his coadjutor and assumed the sovereignty of the prorince, contrary to Turlough's will.

2 The Arrals of Loch Co too mention this 'talse peace,' without comment. 
into Meath, he sent a proclamation round Ireland announcing that he was about to celebrate the fair of Tailtin. ${ }^{7 t}$ Old Donald's representative had probably some high place there, but Turlough was the master and ruler; he and his men of war kept the fair. It was a convention or solemn assembly of the whole island for purposes of commerce, sport, and business. There the genealogists collated and corrected their pedigrees; bards contended for prizes, silent themselves while trained rhapsodists set out to best advantage the fraits of their masters' inventive genius. There were horse races; as when in elder days Macha, the war goddess, though pregnant, ran against the horses of Concobar of the Red Branch Knights. ${ }^{28}$ Thither came the king of Dablin and his Danes, 'famons for gluttony and commerce,' and set up his booths and stalls, exhibiting coats of mail, bright swords, and two-lipped Scandinavian battle-axes. He and his people did not wield them as well as formerly; they found it better to sell them then to handle them. In short, the great fair of Tailtin was, to compare small things with great, just such a festival for these Irish nations as was the Olympic to the states of Greece. It was death to draw weapon in anger, if there were any armed men present save Turlough's. A general peace was proclaimed during its celebration, and it was held impious to hurt any going to or coming from the frir.

Old Donald's flame was now flickering in the socket. Next year he died, and the Ard-Riship of Turlough began, an Ard-Riship than which none was ever stormier, for Turlough's house had no Ard-regal traditions. By pure and sheer force he had to hold down Ireland, and, unlike other Ard-Ris, he would not be content with mere tributes. He would rule and regulate, put up and pluck down, and where he conquered he would be master. Heretofore he had been a sort of lientenant of that famous old northern king; hence to a great extent his success. Henceforth he had to rely on himself alone.

His overlordship of the four southern provinces was not the overlordship of an Ard-Ri; it was of an inferior character in status and dignity, but much superior in power. That overlordship he had now to convert into another form and compel submission to himself in a new character. Obviously, therefore, new wars were to be expected, and duly they came. Turlough's other feudatories seem to have been submissive; not so the king of Desmond or South Manster, the MacCarthy. Old Donald died in 1121, and the same year Turlough descended into Desmond and plun-

37 Telltorn, co. Meath.

" For an animated picture of one of these great fairs the description of the Lair of Garman, by a contemporary bard. It is quoted at length in O'Curry's Mannors and Customs. 
dered South Munster from Fermoy to Tralee, from the Blackwater to the Atlantic. Observe, these plunderings and cattle-drivings, of which we hear so much, were strong coercive strokes of war. When population was sparse and land plenty the ownership of land divested of cattle or other exchangeable property meant subjugation ; permanent military occupation of such territory was not necessary. A chieftain so stripped of his wealth was at the mercy of the man who held it. Hence troops of trained plunderers and cattle-drivers, ' nimble-footed predatory bands,' formed an essential element of an army in the days of Turlough. Such men could follow a trail in the dark, knew how to get the last mile out of driven cattle and to frustrate every effort to provoke a stampede.

In 1122 he crossed the Shannon into Meath, regulating the affairs of that province. While there, encamped by Sally Lake, Enda, king of Leinster, the same who had been with him hanging water robbers on the Shannon, rode into his camp with hostages, some score or so of boys, sons and foster-sons of the chiefs of Leinster and of the Danes. So his Ard-Riship was recognised by Thomond, i.e. the 0'Brians, by Meath, by Leinster, by the Danes. Meantime the recalcitrant MacCarthy had been well stripped in 1121 .

Next year, 1129, he descended into Munster, pitched his camp at Youghal, and took the hostages of Desmond. The stripped chieftains of South Munster came humbly to him, made ample submission, and recovered their property minus arrears of rent. Again full master of four provinces, King Turlough marched home across his plank bridge at Killaloe, past the cathedral where now reposed the remains of Murty O'Brian, Ard-Ri. His wild team had failed to unseat him; Turlough's bit was still in their mouths and his bridle on their necks. His Ard-Riship was of course strengthened by the suppression of this rebellion.

1124. The rebellious MacCarthy died at Cashel, and was succeeded by a notable person, Cormac MacCarthy, builder of the beautiful little church known as Cormac's Chapel, on the Rock of Cashel. Cormac was hardly inaugurated when he too rebelled against Turlough; and being strong at sea, brought a fleet into the estuary of the Shannon and preyed on the commerce of Limerick. Turlough, after hanging the hostages of Desmond, met this move by a bold and well-executed measure. He descended with his strong inland fleet from Lough Ree to Lough Derg, thence, by primitive engineering methods, carried his ships bodily past the rapids of Doonass ${ }^{30}$ into the lower Shannon, and sailed past Limerick into the estuary of the river. He attacked Cormac's fleet in the barbour of Foynes, defeated and captured it, and plundered Kerry at discretion. The king of Meath, Murrough, father of Dervorgilla, and

- The Anrals of Loch Ce say he made two hostings into Desmond in this year.

- Annals of the Four Masters. 
the king of Breffneyrebelled, and the O'Brians threatened to rebel. Turlough planted a great camp in Thomond, to overawe the O'Brians, marched himself against the kings of Meath and Breffney, and beat them in a pitched battle. In the same year he built three strong castles in Connanght-one at Galway, even then a considerable seaport, one at Ballinasloe, and one at Collooney, co. Sligo, all places of great strategic importance. Next year, 1125, he again entered Meath, unresisted, deposed the father of Dervorgilla, set up in his room three lords over the province, and installed as king of Breffney a young friendly O'Rourke named Tiernan, future husband of Dervorgilla. All this time the architectural Cormac was in a state of rebellion, but his destruction was drawing nigh.

1126. Enda, who helped in the clearing of the Shannon and came to him at Sally Lake with the hostages, died. Turlough forthwith made a new hosting, marched into Leinster and inaugurated his own infant son, Conor O'Conor, as king of the province ${ }^{31}$ a high essumption of power. He beat Cormac of the chapel there in a pitched battle, and demolished his stationary camp, which was in the hills above Kilkenny. Planting a new camp of his own in Ormond (co. Tipperary) he reached out thence long predatory arms, one as far as Waterford, another as far as Cork, and anbdued and took the hostages of all Leinster, giving them into the hands of the council which governed in the name of the infent king.

Next year, 1127, he marched to Cork, and in a solemn convention of the southern chiefs held in that city deposed Cormas the architectural, and sent him to Lismore as a monk, putting in his place a certain Donald MacCarthy, friendly to him and his ArdRiship. Those who are familiar with the history of the sixteenth century know that the subjugation of the earl of Desmond was regarded as a great achievement. Yet the overthrow of Cormac, king of the same territory, by Turlough was a more brilliant affair ; for Cormac was head of a confederacy which embraced the south of Leinster as well as Desmond, while the Elizabethan generals were zealously supported by the powerful clan of the Butlers.82 Again, the conquest of Cormac was but one of innumerable feats of arms performed by Turlough, dim and of little moment as they may now seem. Finally he had another considerable war on hand at the same time, viz. that in which he subdued the allied kinge of Breffney and Meath.

In this year (1127) Turlough reached the height of his power and glory. He may have been as great in after periods of his career, but I think was never greater. Moreover he was atill young and

" And king of Ath.Clia, or Dublin and its maritime dependencies.

as A clan almost as powerfal as the Geraldines and most ably commanded by the earl of Ormond, Black Thomas the Butler. 
could enjoy his success and his fame. He was but in the thirtyninth year of his age. He was Ard-Ri, in the old titular signification, of all Ireland and king, in the sense of master of four provinces and of whatever insular sovereignty and maritime power was then held by the Danes of Dublin. The young king of Breffney, Tiernan O'Rourke, was his vassal. Over the strong kingdom of Meath he had three subject lords, appointed by himself. His own son was king of Leinster. Thomond and the powerful house of 0 'Brian were divided under two kings and so neutralised. He had there too a third 0'Brian brother, Teigue the Chaste, devoted to his interest and ready to his hand should Conor Slapar-Salach and Turlough turn against him. Desmond was held by a MacCarthy, who owed his appointment to himself, sustained by a military colony of 2,000 of the Ard-Ri's own trained warriors.

This seems a good point at which to take leave of the story of Turlough, for whom, however, were reserved thirty-one years more of stormy life.

Of Turlough's personal appearance, save that he was tall and presumably handsome, or at least distinguished-looking, we can guess nothing. The student may imagine a tall figure wearing the Scandinavian helmet with projecting narrow face-guard, shirt of chain mail, part covered by a scarlet mantle fastened on the breast with a curiously carred wheel-brooch, close-fitting trews or hose, with shoes plaited with thin flakes of bright bronze; holding ever in his hand for sceptre or wand a long battle-axe; grave, perhaps stern, of aspect, but with some under-light of tenderness and goodwill, for the chroniclers tell us that he was ' full of chivalry and hospitality, mercy and compassion.' As a boy he had received the best education which those times allowed, for he had been brought up under the eye of his foster father, Murty O'Brian, Ard-Ri, by far the most distinguished man of his time, and by him trained in war, diplomacy, and administration, es those arts were anderstood in that rude time. From him too he derived his piety and respect for religious persons, for Murty was a pious prince. He gave Cashel to the clergy, and otherwise took a great interest in ecclesiastical affairs, so that the good St. Anselm wished him prosperity and length of days. The reader will recall that graceful act of young Turlough when he restored the captives ' to God and to Flannan,' thereby voluntarily denuding himself of much wealth, for war captives were then sold into slarery.

I have no doubt that according to his lights he tried to govern with justice. The chroniclers tell us that he had for chancellor one Gilla-na-Naomh O'Carty, i.e. Servant of the Saints O'Carty, 'supreme lawgiver of the Grel.' In other words, Turlough's chief

- A man, observe, as to whom the good 8t. Ansalm wrote that he had him ever in his prajerg. 
minister was one universally respected, a fact as creditable to his lord as to himself. Two powerful dynasts, one a strong revolter, the other a rival for the Ard-Riship, he subdued without killing or blinding - merely sent them to Lismore as monks. He cleared the Shannon of water robbers and built many bridges and many castles, and is seid to have coined money at Clonmicnoise. This, whether literally true or false, indicates that he paid attention to the economic province of administration. He had the wisdom to perceive that the era of strong, masterful kinga had arrived, and the courage and resolation to stand by that perception.

It is curious, bat a fact, that Turlough O'Conor was unconsciously conquering Ireland for the Normans. It was owing to the labours of Tarlough, of his successors and his predecessors, that this island became conquerable by Henry II and the conquistadores. These Irish dynasts battle-axed the tribal communities into solidarity, and accustomed the minds of the inhabitants to the idea of great feudal supremacies and overlordships. So the Ard Riship of Henry FitzEmpress came upon them without a shock. To the MacMurroughs of Leinster the Plantagenets were hardly more strange than the $0^{\prime}$ Conors. The $0^{\prime}$ Conors had put an $0^{\prime}$ Conor over them as king; ${ }^{34}$ why should not the son of an empress set over them an earl? Turlough afterwards set up that same boy as king of Meath.w To the 0'Melaghlins, clan regnant of that province, it was not a stranger proceeding when the potent Angevin gave them as their lord Hugo de Lacy. Ireland in the tribal state would have, I think, proved unconquerable to the Normans; but those Irish Ard-Ris had established a solidarity of the tribes sufficiently strong to permit the supremacy of the Angevins, and yet not perfect enough to defeat and repel it. Shall we aay, then, that the lives of men like Turlough were, from an Irish point of view, worse than wasted? Well, I think not; but the question is too profound to be here discussed. STANDish O'Grady.

" Conor O'Conor, Tarlough's inlant son.

4 See Anrals of the Four Mastors, 1144, an important fact. 